\title{
UJI AKTIVITAS ANTIBAKTERI SPRAY BAU KAKI EKSTRAK KULIT JERUK NIPIS (Citrus aurantifolia) DENGAN VARIASI Gelling agent TERHADAP BAKTERI Bacillus subtilis
}

\author{
Ade Maria Ulfa ${ }^{1}$, Nofita ${ }^{2}$, Bangun Saras Sandi ${ }^{3}$ \\ ${ }_{1}^{1}$ Program Studi Farmasi Universitas Malahayati Bandar Lampung \\ ${ }^{2}$ Program Studi Farmasi Universitas Malahayati Bandar Lampung \\ Email : adeulfa81@yahoo.co.id/082181059969
}

\begin{abstract}
Sweat is produced by the apocrine glands, if infected by bacteria that play a role in the decay process will certainly produce foot odor. Some of the bacteria that cause, including Staphylococcus epidermis, Corynebacterium acne and there is one bacterium that causes pungent foot odor that is Bacillus subtilis. Bacillus subtilis enzyme leucine dehydrogenase produced the highest, resulting in isovaleric acid foot odor. Lime peel (Citrus aurantifolia) has the potential to be developed for the antibacterial active ingredient of foot odor contained in tannins, alkaloids and flavonoids. Spray can be effective for inhibition of feet due to water fleas or bacterial infections. The purpose of this research is to test the inhibitory zone of the preparation of foot odor spray ethanol extract of lime peel (Citrus aurantifolia) with variations of gelling agent. Bacterial inhibition zone testing on extracts of lime peel spray preparations using the disc method. This test was carried out on spray with extract concentration of $0 \%$ extract base carbopol, $0 \%$ extract base HPMC, $0.2 \%$ extract base carbopol, $0.2 \%$ extract base HPMC, $0.4 \%$ extract base carbopol, $0.4 \%$ extract base HPMC and positive control with an average inhibition zone of $9,13 \mathrm{~mm}, 9,12 \mathrm{~mm}, 11,86 \mathrm{~mm}, 11,29 \mathrm{~mm}, 13,17 \mathrm{~mm}, 12,30$ $\mathrm{mm}, 8,13 \mathrm{~mm}$ against the bacterium Bacillus subtilis. Antibacterial test results were analyzed using ONE WAY ANOVA, the results of statistical analysis on the preparation of lime peel extract showed a significant inhibition zone difference of $0.000(P=<0.05)$ between all concentrations. Lime peel extract spray is effective in inhibiting the bacterium Bacillus subtilis.
\end{abstract}

Key words: Sweat of foot odor, Lime skin (Citrus aurantifolia), Spray, bacteri Bacillus subtilis

\section{ABSTRAK}

Keringat dihasilkan oleh kelenjar apokrin, jika terinfeksi oleh bakteri yang berperan dalam proses pembusukan tentunya akan menghasilkan bau kaki. Beberapa bakteri yang menjadi penyebab, diantaranya adalah Staphylococcus epidermis, Corynebacterium acne dan ada satu bakteri yang menyebabkan bau kaki menyengat yaitu Bacillus subtilis. Bacillus subtilis menghasilkan enzim leusin dehydrogenase yang dihasilkan paling tinggi, sehingga terbentuk asam isovalerat yang menyebabkan bau kaki. Kulit jeruk nipis (Citrus aurantifolia) berpotensi dikembangkan untuk bahan aktif antibakteri bau kaki yang terdapat dalam kandungan tanin, alkaloid dan flavonoid. Spray dapat efektif untuk penghambatan bau kaki karna infeksi bakteri. Tujuan penelitian yang dilakukan yakni uji zona hambat sediaan spray bau kaki ekstrak etanol kulit jeruk nipis (Citrus aurantifolia) dengan variasi gelling agent. Pengujian zona hambat bakteri pada ekstrak kulit jeruk nipis sediaan spray menggunakan metode cakram. Pengujian ini dilakukan pada spray dengan konsentrasi esktrak $0 \%$ ekstrak basis karbopol, $0 \%$ ekstrak basis HPMC, 0,2\% ekstrak basis karbopol, $0,2 \%$ ekstrak basis HPMC, $0,4 \%$ ekstrak basis karbopol, $0,4 \%$ ekstrak basis HPMC dan kontrol positif dengan rata-rata zona hambat $9,13 \mathrm{~mm}, 9,12 \mathrm{~mm}, 11,86 \mathrm{~mm}, 11,29 \mathrm{~mm}, 13,17 \mathrm{~mm}, 12,30 \mathrm{~mm}, 8,13 \mathrm{~mm}$ 
terhadap bakteri Bacillus subtilis. Hasil uji antibakteri dianalisis menggunakan ONE WAY ANOVA, pada hasil analisis statistik pada sediaan spray ekstrak kulit jeruk nipis menunjukan adanya perbedaan zona hambat yang signifikan yaitu $0,000 \quad(P=<0,05)$ antara seluruh konsentrasi. Sediaan spray ekstrak kulit jeruk nipis efektif dalam menghambat bakteri Bacillus subtilis.

Kata kunci : Keringat bau kaki, Kulit jeruk nipis (Citrus aurantifolia), Spray, Bakteri Bacillus subtilis

\section{PENDAHULUAN}

Peningkatan suhu di bumi menjadi suatu kondisi yang menyebabkan tidak sedikit dari manusia mengalami pengeluaran keringat dengan frekuensi lebih sering dan bahkan dalam jumlah yang lebih banyaksehingga terjadi kelembaban. bagian tubuh yang sering mengalami keringat adalah kaki. Keadaan kaki yang sering tertutup kaos kaki serta suhu yang tinggi dapat menjadi salah satu faktor timbulnya masalah pada kaki, salah satunya adalah bau tidak sedap pada kaki (The Society of Chiropodists \& Pediatrists, 2011).

Tahun 2014 American Podiatric Medical Association (APMA) melakukan survei terhadap 1021 orang dewasa (berusia 18 tahun atau lebih) terkait masalah di kaki dan menemukan berbagai hasil menarik. Sejak tahun 2010, bagian kaki masih menjadi bagian yang kurang diperhatikan oleh masyarakat Amerika. Namun, bertentangan dengan hal tersebut, delapan dari 10 orang Amerika mengaku mengalami permasalahan dengan kaki. (American Podiatric Medical Association, 2014).

Keringat dihasilkan oleh kelenjar apokrin, jika terinfeksi oleh bakteri yang berperan dalam proses pembusukan tentunya akan menghasilkan bau kaki. Beberapa bakteri yang menjadi penyebab, diantaranya adalah Staphylococcus epidermidis, Coryne-bacterium acne, Streptococcus pyogenes (Rianta dan Febrianti, 2018) dan ada salah satu bakteri yang menyebabkan bau kaki tidak enak atau menyengat yaitu Bacillus subtilis ( Ara dkk., 2006).

Bacillus subtilis menyebabkan timbulnya bau tidak sedap dan menyengat akibat enzim leusin dehydroginase yang dihasillkan paling tinggi, sehingga terbentuk asam isovalerat sehingga dapat menyebabkan bau kaki yang menyengat. permasalahan tersebut dapat diatasi salah satunya penggunaan antibakteri yang mampu menghambat aktivitas pertumbuhan bakteri penyebab bau kaki. (Ara dkk., 2006).

Antibakteri merupakan suatu senyawa yang terdapat dalam suatu organisme sebagai metabolit sekunder dan sebagai penghambat bakteri. Senyawa tersebut memiliki aktivitas merusak dinding sel, menghambat kerja enzim, mengganggu sintesis ptotein, mengubah permeabilitas membran (Septiani dkk., 2017).

Di era modern ini masyarakat Indonesia menggunakan bahan alam dalam mengobati suatu penyakit. Tanaman yang dipakai salah satunya yaitu jeruk nipis. Tanaman ini mudah di temukan di Indonesia dengan harga yang relatif murah (Enejoh, dkk, 2015). Kulit jeruk nipis mengandung flavonoid yang dapat digunakan sebagai antibakteri (Adindaputri, 2013).

Flavonoid merupakan suatu golongan terbesar dari senyawa polifenol yang dapat bekerja sebagai antioksidan dan juga sebagai antibakteri dengan mendenaturasi protein sel bakteri dan 
merusak sel bakteri (Pelczar dkk, 1988). Selain itu kulit jeruk nipis juga memiliki kandungan lain yang bermanfaat sebagai antibakteri, antara lain: tanin, flavonoid, dan alkaloid yang diduga dapat memberikan efek antibakteri (Ashfia dkk, 2019).

Seiring perkembangan zaman sediaan anti bau kaki telah banyak diproduksi, seperti sabun dan bodyscrub antibakteri. Salah satu sediaan farmasi yang masih jarang ditemui adalah bentuk spray, yang digunakan pada kaki (ashfia dkk,2019). Menurut Santoso dan Riyanta (2019) kandungan utama pada sediaan spray adalah alkohol, dimana efek antimikroba dapat dihasilkan dengan baik ketika sediaan memiliki kandungan alkohol, dan untuk meningkatkan kestabilan spray dan kekentalan agar efeknya bertahan lama dapat ditambahkan dengan gelling agent contohnya karbopol dan HPMC.

Karbopol, sebuah polimer asam arklirat, memiliki sifat hidrofilik yang stabil. Sediaan spray dibuat sedikit kental, untuk menjaga kestabilan kandungan di dalam sediaan. Oleh karena itu, pembuatan sediaan spray menggunakan salah satu komponen kompleks gel, yakni Karbopol - $\mathrm{NaOH}$, yang perbandingan konsentrasinya sangat rendah $(0,06: 0,024)$, agar sediaan spray tetap dapat mengalir, namun sedikit kental. Perbandingan konsentrasi tersebut didapatkan setelah optimasi terhadap sediaan yang terbentuk (Iswandana dan Lidya, 2017). Selain itu ada pula HPMC yang merupakan gelling agent yang memiliki viskositas yang stabil dan cairan jernih (Rowe, 2009).

Berdasarkan ulasan di atas, kulit buah jeruk nipis (Citrus aurantifolia ) bisa dimanfaatkan sebagai antibakteri pada bakteri Bacillus subtilis yang menyebabkan timbulnya bau kaki. Penelitian yang dilakukan yakni uji zona hambat sediaan spray bau kaki ekstrak etanol kulit jeruk nipis (Citrus aurantifolia) dengan variasi gelling agent dan stabilitas fisik dengan penambahan gelling agent yang berbeda.

\section{METODE PENELITIAN}

\section{Alat dan Bahan}

Alat-alat yang akan digunakan pada pengujian ini yaitu timbangan analitik, gilingan, gelas ukur, erlenmeyer, penangas air, kaca arloji, mortar dan stamper, cawan porselen, kertas perkamen, oven, rotary evaorator, botol semprot, cawan petri, tabung reaksi, kertas kopi, benang nilon, autoclave pinset, viskometer oswald, magnetic stirer, pipet tetes, pipet ukur, balp, katenbat, dan laminar air flow.

Bahan-bahan yang akan digunakan pada penelitian ini antara lain Nutrient Agar (NA), etanol $96 \%$, Isopropil alkohol, asam askorbat, Propilenglikol, Tween 80, Gliserin, $\mathrm{NaOH}$, Karbopol, HPMC, Aquadest, $\mathrm{NaCL}$, dan kulit jeruk nipis (Citrus aurantifolia).

\section{PREPARASI SAMPEL}

Kulit jeruk nipis yang telah dipilih dan dibersihkan kemudian di keringkan dengan cara diangin-anginkan tanpa cahaya matahari. Sampel yang kering diserbuk menggunakan mesin penggilingan, hasilnya dimasukan kedalam wadah tertutup.

Metode ektraksi yang digunakan adalah maserasi menggunakan pelarut etanol 96 $\%$. Serbuk simplisia kulit jeruk nipis ditimbang sebanyak 500 gram kemudian dimasukan kedalam maserator yang bagian dasarnya telah dilapisi kapas, kemudian dimasukan pelarut etanol $96 \%$ kedalam maserator hingga simplisia tersebut terendam seluruhnya. Diamkan selama $5 \times 24$ jam, dan setiap 24 jam pelarut diganti dengan pelarut yang baru hingga filtrat yang dihasilkan jernih. Hasil ekstraksi yang diperoleh dipekatkan dengan menggunakan alat vacuum rotary 
evaporator dilanjutkan dengan waterbath (Hindun dkk, 2017).

\section{Skrining fitokimia}

1. Identifikas Alkaloid (Hanani, 2008)

Siapkan tabung reaksi kemudian masukkan $2 \mathrm{ml}$ ekstrak tambahkan larutan $5 \mathrm{ml} \mathrm{HCL}$. Setelah itu larutan ditambahkan pereaksi mayer. Hasil positif ditandai dengan adanya kabut putih atau endapan putih saat ditambahkan pereaksi mayer.

2. Identifkasi Flavonoid (Hanani, 2008)

Penambahan larutan besi (III) Korida. Larutan yang di uji akan menimbulkan warna merah setelah penambahan larutan.

3. Identifikasi Tanin (Hanani, 2008)

Larutan uji sebanyak $5 \mathrm{ml}$ ditambahkan larutan gelatin $1 \%$ sebanyak $2 \mathrm{ml}$, lalu diamati dan akan hasil positif mengandung tanin ditandai dengan adanya endapan putih dan berwarna coklat kehitaman.

\section{Pembuatan formulasi sediaan spray}

1. Formula spray dapat dilihat pada Tabel 1 Pada tahap pertama, karbopol 940 didispersikan di dalam sejumlah air erlenmayer. Pada wadah terpisah, $\mathrm{NaOH}$ dilarutkan dengan air. Pada tahap berikutnya, campuran karbopol 940 dengan air dicampurkan dengan $\mathrm{NaOH}$. Selanjutnya, ke dalam larutan ini, ditambahkan propilen glikol dan diaduk hingga homogen. lalu, ditambahkan vitamin (campuran A).

2. Pada wadah terpisah, ekstrak etanol $96 \%$ kulit jeruk nipis dilarutkan secukupnya ke dalam isopropil alkohol. Setelah ekstrak etanol kulit jeruk nipis larut, ditambahkan $0,5 \mathrm{~g}$ mentol dihomogenisasi hingga homogen. Kemudian, 0,2 $\mathrm{ml}$ gliserin ditambahkan dan dihomogenisasi hingga bercampur, lalu ditambahkan pewangi dan dihomogenkan hingga bercampur (campuran B).

3. Campuran $B$ ditambahkan ke dalam campuran sediaan $A$, dihomogenkan hingga benar-benar bercampur. Selanjutnya, tambahkan solubilizing agent, yaitu Tween 80 .

Tabel 1. Rencana Formulasi sediaan spray mengacu pada penelitian Iswandana dan Lidya (2017).

\begin{tabular}{|c|c|c|c|c|c|c|c|}
\hline \multirow[t]{2}{*}{ Bahan } & \multicolumn{4}{|c|}{ Konsentrasi ( \% b/v) } & \multirow[b]{2}{*}{$\begin{array}{c}\text { Kontrol } \\
(-)\end{array}$} & \multirow[b]{2}{*}{$\begin{array}{c}\text { Kontrol } \\
(-)\end{array}$} & \multirow[b]{2}{*}{$\begin{array}{c}\text { Kontrol } \\
(+)\end{array}$} \\
\hline & $\begin{array}{c}\text { Formula } \\
1\end{array}$ & $\begin{array}{c}\text { Formula } \\
2\end{array}$ & $\underset{3}{\text { Formula }}$ & $\begin{array}{c}\text { Formula } \\
4\end{array}$ & & & \\
\hline $\begin{array}{c}\text { Ekstrak } \\
\text { kulit jeruk } \\
\text { nipis }\end{array}$ & 0,2 & 0,4 & 0,2 & 0,4 & - & - & $\begin{array}{l}\text { Sediaan } \\
\text { spray } \\
\text { komersil }\end{array}$ \\
\hline $\begin{array}{c}\text { Asam } \\
\text { askorbat }\end{array}$ & 0,2 & 0,2 & 0,2 & 0,2 & 0,2 & 0,2 & (Bio \\
\hline Gliserin & 0,2 & 0,2 & 0,2 & 0,2 & 0,2 & 0,2 & Herbal) \\
\hline $\begin{array}{l}\text { Isopropil } \\
\text { alkohol }\end{array}$ & 25 & 25 & 25 & 25 & 25 & 25 & \\
\hline Mentol & 0,5 & 0,5 & 0,5 & 0,5 & 0,5 & 0,5 & \\
\hline $\begin{array}{l}\text { Propilen } \\
\text { glikol }\end{array}$ & 5 & 5 & 5 & 5 & 5 & 5 & \\
\hline $\begin{array}{c}\text { Karbopol } \\
940\end{array}$ & 0,06 & 0,06 & - & - & 0,06 & - & \\
\hline
\end{tabular}




$\begin{array}{ccccccc}\text { HPMC } & - & - & 0,06 & 0,06 & 0,06 & 0,06 \\ \text { NaOH } & 0,024 & 0,024 & 0,024 & 0,024 & 0,024 & 0,024 \\ \begin{array}{c}\text { Pewangi } \\ \text { lemon }\end{array} & 0,5 & 0,5 & 0,5 & 0,5 & 0,5 & 0,5 \\ \begin{array}{c}\text { Tween } 80 \\ \text { Aquadest }\end{array} & 4,3 & 4,3 & 4,3 & 4,3 & 4,3 & 4,3 \\ & \text { ad. } 100 & \text { ad. } 100 & \text { ad. } 100 & \text { ad. } 100 & \text { ad. } 100 & \text { Ad. } 100\end{array}$

\section{Evaluasi sediaan spray}

1. Uji stabilitas fisik

Pengujian dilakukan dengan cara menyimpan sediaan pada suhu $4^{\circ} \mathrm{C}$ salama 48 jam dan dilanjutkan dengan menyimpan sediaan pada suhu $40^{\circ} \mathrm{C}$ selama 48 jam satu siklus. Pengujian dilakuan sebanyak 3 siklus.

a. Pengamatan organoleptis.

Sediaan diamati bau, warna, dan aroma secara kualitatif.

b. Pengukuran $\mathrm{pH}$

Pengukuran derajat keasaman menggunakan $\mathrm{pH}$ meter. Pengukuran dilakukan pada suhu ruang.

2. Uji kejernihan

Uji kejernihan bertujuan untuk mengetahui apakah sediaan Spray jernih atau tidak, sediaan Spray sebaiknya harus bebas partikel.
3. Uji viskositas

Uji viskositas bertujuan untuk mengetahui tingkat kekentalan suatu sediaan. Pengukuran viskositas ini menggunakan Viskometer Ostwald pada temperatur $25^{\circ} \mathrm{C}$ dengan viskositas air 0,8904 Cp .

\section{Langkah-langkah Uji Aktivitas Antibakteri}

Alat dan bahan yang akan digunakan dalam penelitian disterilisasi untuk menghindari terjadinya kontaminasi dalam pengujian. Pembuatan media agar NA. Penyiapan Mikroorganisme Uji. Tahap Perlakuan Pembuatan cakram spray ekstrak kulit jeruk nipis menggunakan metode celup (immersion method). Dalam konsentrasi yang dibuat, cakram direndam kemudian masukkan ke petri dalam inkubator dengan suhu $37^{\circ} \mathrm{C}$ selama 16 18 jam mengacu pada CLSI (2011). Kemudian di keluarkan dan dilakukan pengukuran diameter zona hambat dengan penggaris atau jangka sorong. Dilakukan pengulangan sebanyak 3 kali.

\section{HASIL DAN PEMBAHASAN}

\section{Hasil}

Tabel 2. Hasil Uji Fitokimia Ekstrak kulit jeruk nipis (Citrus aurantifolia).

\begin{tabular}{llll}
\hline No. & Senyawa & \multicolumn{1}{c}{ Warna yang terbentuk } & Hasil \\
\hline 1. & Alkaloid & $\begin{array}{l}\text { Merah bata dan terbentuk endapan } \\
\text { putih }\end{array}$ & Positif \\
2. & Flavonoid & $\begin{array}{l}\text { Merah bata } \\
\text { Coklat kehitaman }\end{array}$ & Positif \\
\hline
\end{tabular}


Tabel 3. Hasil Uji pH Sediaan

\begin{tabular}{|c|c|c|c|}
\hline No & Sediaan & $\begin{array}{l}\text { pH sebelum uji } \\
\text { stabilitas }\end{array}$ & $\begin{array}{l}\text { pH sesudah uji } \\
\text { stabilitas }\end{array}$ \\
\hline 1. & Formulasi I & 4,8 & 5,4 \\
\hline 2. & Formulasi II & 5,1 & 5,2 \\
\hline 3. & Formulasi III & 4,7 & 5,1 \\
\hline 4. & Formulasi IV & 5,2 & 5,3 \\
\hline 5. & KN HPMC & 5,2 & 6,0 \\
\hline 6. & KN Karbopol & 5,7 & 5,7 \\
\hline
\end{tabular}

Tabel 4. Hasil Uji Kejernihan

\begin{tabular}{lll}
\hline No. & \multicolumn{1}{c}{ Sediaan } & \multicolumn{1}{c}{ Kejernihan } \\
\hline 1. & Formulasi I & Jernih tidak ada butiran-butiran melayang \\
2. & Formulasi II & Jernih tidak ada butiran-butiran melayang \\
3. & Formulasi III & Jernih tidak ada butiran-butiran melayang \\
4. & Formulasi IV & Jernih tidak ada butiran-butiran melayang \\
5. & KN HPMC & Jernih tidak ada butiran-butiran melayang \\
6. & KN Karbopol & Jernih tidak ada butiran-butiran melayang \\
\hline
\end{tabular}

Tabel 5. Hasil Uji Viskositas sediaan spray

\begin{tabular}{llc}
\hline No. & \multicolumn{1}{c}{ Sediaan } & Viskositas (Cp) \\
\hline & & \\
1. & Formulasi I & 1,444 \\
2. & Formulasi II & 1,494 \\
3. & Formulasi III & 1,967 \\
4. & Formulasi IV & 2,318 \\
5. & KN HPMC & 1,701 \\
6. & KN Karbopol & 1,363 \\
\hline
\end{tabular}

Tabel 6. Hasil Zona Hambat Spray

\begin{tabular}{|c|c|c|c|c|c|c|}
\hline \multirow{3}{*}{ No. } & \multirow{3}{*}{ Sediaan } & \multirow{2}{*}{\multicolumn{3}{|c|}{$\begin{array}{l}\text { Diameter Rata-rata } \\
\text { Zona hambat }(\mathrm{mm}) \\
\text { Penqulanqan }\end{array}$}} & \multirow{3}{*}{$\begin{array}{l}\text { Rerata Zona } \\
\text { Hambat } \pm S D \\
(\mathrm{~mm})\end{array}$} & \multirow{3}{*}{ P-value } \\
\hline & & & & & & \\
\hline & & I & II & III & & \\
\hline 1. & Formulasi I & 11,89 & 11,79 & 11,92 & $11,86 \pm 0,06$ & \\
\hline 2. & Formulasi II & 13,17 & 13,20 & 13,16 & $13,17 \pm 0,02$ & \\
\hline 3. & Formulasi III & 11,29 & 11,32 & 11,26 & $11,29 \pm 0,03$ & 0,000 \\
\hline 4. & Formulasi IV & 12,28 & 12,30 & 12,33 & $12,30 \pm 0,02$ & \\
\hline 5. & KN HPMC & 9,10 & 9,12 & 9,16 & $9,12 \pm 0,03$ & \\
\hline 6. & KN Karbopol & 9,12 & 9,14 & 9,13 & $9,13 \pm 0,01$ & \\
\hline 7. & Kontrol Positif & 8,11 & 8,15 & 8,13 & $8,13 \pm 0,02$ & \\
\hline
\end{tabular}

Keterangan :

Formulasi I : Konsentrasi ekstrak $0,2 \%$ dengan basis karbopol 
Formulasi II

Formulasi III

Formulasi IV

KN HPMC

KN Karbopol

$\mathrm{KP}$
: Konsentrasi ekstrak 0,4\% dengan basis karbopol

: Konsentrasi ekstrak 0,2\% dengan basis HPMC

: Konsentrasi ekstrak 0,4\% dengan basis HPMC

: Konsentrasi basis HPMC tanpa ekstrak

: Konsentrasi basis Karbopol tanpa ekstrak

: Kontrol positif sediaan komersil

\section{PEMBAHASAN}

Pada penelitian ini dilakukan terhadap kulit jeruk nipis (Citrus aurantifolia) dalam sediaan spray bau kaki yang dapat menghambat bakteri bacillus subtilis. Sebelum sediaan di uji aktivitas antibakteri terlebih dahulu dilakukan uji fitokimia dan evaluasi fisik sediaan.

Uji fitokimia ekstrak kulit jeruk nipis berpotensi dikembangkan sebagai bahan aktifkarena positif mengandung senyawa tanin, alkaloid dan flavonoid. Hal tersebut, menunjukan bahwa etanol yang digunakan sebagai pelarut mampu menarik senyawa-senyawa tersebut. Berdasarkan Penelitian kandungan senyawa kulit jeruk nipis yaitu tanin, flavonoid dan alkaloid dapat berfungsi sebagai antibakteri (ashfia dkk, 2019).

Sebelum melakukan uji aktivitas bakteri, terlebih dahulu membuat sediaan spray dengan empat formulasi dengan konsentrasi $0,2 \%, 0,4 \%, 0,2 \%, 0,4$, kontrol positif dan negatif. Bahan yang digunakan yaitu karbopol yang sering digunakan sebagai gelling agent. Alasan penggunaan karbopol karna pembuatan spray dibuat agak kental tetapi tetap dapat mengalir untuk menjaga kestabilan kandungan di dalam sediaan. Karbopol merupakan komponen yang kompatibel dengan bahan lain, tidak meninggalkan bekas dikulit dan tidak iritasi. Kemudian HPMC yang digunakan sebagai pembanding dalam penelitian ini. HPMC merupakan basis gel yang baik juga kompatibel dengan bahan lain dan tidak meninggalkan kerak. Setelah pembuatan sediaan dilakukan uji evaluasi fisik yang pertama uji stabilitas fisik. Hasil uji organoleptik meliputi warna, bau dan bentuk. Sediaan spray yang dibuat memiliki bentuk cair, sesuai dengan karakteristik spray. Kemudian bau sediaan adalah strawberry dan mint yang dihasilkan dari bahan mentol yang digunakan. Warna sediaan beragam ada yang kuning tua dan muda. Hal ini disebabkan oleh konsentrasi ekstrak yang di tambahkan, semakin besar konsentrasi semakin banyak juga ekstrak yang ditambahkan dan warna akan semakin terang. Kemudian dilakukan pengamatan setelah uji stabilitas dan tidak terjadi perubahan apapun pada organoleptik sediaan.

Uji pH dilakukan untuk mengetahui derajat keasaman dan aman atau tidaknya sediaan saat digunakan di kulit sehingga tidak menyebabkan iritasi. Hasil uji pH konsentrasi I, II, III, IV, dua kontrol negatif dan kontrol positif dengan $\mathrm{pH} 4,8,5,1,4,7$, $5,2,5,2,5,7$, dan 5,1. Nilai $\mathrm{pH}$ yang dihasilkan memenuhi persyaratan karna berada di antara 4,5 sampai 6,5 . Hasil uji $\mathrm{pH}$ sesuai dengan penelitian (Ashfia dkk, 2019) dimana rentang $\mathrm{pH}$ dengan formulasi yang sama menghasil kan nilai $\mathrm{pH}$ 5-6. Kemudian di uji kembali setelah stabilitas sediaan hasilnya terjadi perubahan $\mathrm{pH}$ sediaan tetapi berkisar 5,16,0 sehingga di asumsikan masih memenuhi persyaratan untuk digunakan pada kulit masih aman dan tidak menyebabkan iritasi karna $\mathrm{pH}$ kulit antara $\mathrm{pH}$ 4,5-6,5. Nilai $\mathrm{pH}$ yang terlalu asam akan menyebabkan iritasi kulit dan $\mathrm{pH}$ yang terlalu basa akan menyebabkan kulit kering (Ashfia dkk, 2019). Stabilitas suatu sediaan dipengaruhi oleh bahan pembawa yang baik. Menurut penelitian (Iswandana 
dan Lidya, 2017) bahan pembawa yang digunakan yaitu tween 80 yang dapat menjaga kestabilan sediaan dengan baik. Hal ini sesuai dengan literature (White,1964) dimana tween 80 dapat menentukkan stabilitas fisik sediaan, karena dengan adanya tween 80 sediaan akan homogen dan tween 80 tidak terionisasi dalam larutan. Dalam konsentrasi $1-10 \%$ baik digunakan sebagai solublizing agent sehingga sediaan yang dibuat hasilnya baik dan stabil.

Uji kejernihan dilakukan untuk melihat jernih atau tidaknya sediaan dan bebas dari partikel atau butiran. Dari hasil yang di dapat bahwa semua memenuhi persyaratan karna sediaan spray sebaiknya jernih dan tidak ada butiran atau partikel bebas (Riyanta dan Febriyanti, 2018).

Uji viskositas dilakukan untuk mengetahui tingkat kekentalan suatu sediaan. Secara berturut-turut dari formula 1, 2, 3, 4 dan dua kontrol negatif menghasilkan 1,444 poise, 1,494 poise, 1,967 poise, 2,318 poise, 1,363 poise, dan 1,701 poise. Hasil ini sebanding dengan penelitian (ashfia, dkk) dimana semakin tinggi nilai ekstrak yang ditambahkan akan semakin tinggi nilai viskositasnya. Kemudian terjadi viskositas yang terlalu kental pada sediaan dengan basis HPMC. Hal ini disebabkan basis karbopol yang digunakan memiliki sifat hidroalkohol dan dapat digunakan sebagai thickener agent yang lebih efisien karna mempunyai sifat alir yang baik sesuai dengan penggunaan dengan disemprot dibandingkan HPMC yang membuat sediaan lebih kental, memiliki warna keruh dan menghasilkan daya sebar yang kurang baik (Anonim, 2011).

Pada penelitian ini rata-rata zona hambat terhadap bakteri Bacillus subtilis pada konsentrasi 0,2\% ekstrak basis karbopol mendapatkan zona hambat sebesar 11,86 $\mathrm{mm}$, pada konsentrasi ekstrak 0,4 \% basis karbopol mendapatkan zona hambat sebesar 13,17 $\mathrm{mm}$, pada konsentrasi ekstrak 0,2 \% basis HPMC mendapatkan zona hambat sebesar 11,29 $\mathrm{mm}$, konsentrasi ekstrak $0,4 \%$ basis HPMC mendapatkan zona hambat $12,30 \mathrm{~mm}$. Kontrol negatif basis karbopol mendapatkan zona hambat $9,13 \mathrm{~mm}$, kontrol negatif basis HPMC mendapatkan zona hambat 9,12 $\mathrm{mm}$, dan kontrol positif spray komersil mendapatkan zona hambat $8,13 \mathrm{~mm}$. Hal ini sesuai dengan penelitian (ashfia dkk, 2019) dalam konsentrasi 0,15 $\%$ ekstrak kulit jeruk nipis sudah dapat menghambat bakteri bau kaki sebesar 1 $\mathrm{mm}$. Dari semua formulasi sediaan memenuhi standar kuat $(10-20 \mathrm{~mm})$ (Davis dan Stout, 1971).

\section{KESIMPULAN}

Sediaan spray bau kaki ekstrak kulit jeruk nipis (Citrus aurantifolia) dengan variasi gelling agent yang mempunyai sifat fisik paling baik yaitu yang menggunakan basis karbopol karna dalam uji evaluasi mencakup hasil lebih baik dari pada basis HPMC dan dengan konsentrasi ekstrak $0,4 \%$ basis karbopol memiliki zona hambat terhadap bakteri paling baik sebesar 13,30 mm termasuk kategori kuat.

\section{DAFTAR PUSTAKA}

Adindaputri Z, Purwanti N., \& Wahyudi I.A. 2013. Pengaruh Ekstrak Kulit Jeruk Nipis (Citrus Aurantifolia Swingle) Konsentrasi $10 \%$ Terhadap Aktivitas Enzim Glukosiltransferase Streptococcus mutans. Jurnal UGM. Vol.20, No.2: Hal 126-131

American Podiatric Medical Asociation 2014. Public Opinion Research On Foot Health And Care. USA: APMA. PP. 3-7 
Anonim, 2011, Farmakope indonesia. Departemen Kesehatan RI, Jakarta.

Ara, K., Masakatsu H., Syunichi A., Kenzo K.,Koichi O., Toyoki H., et al., 2006, The Odor Due To Microbial Metabolism And Its Control, can. J.Microbial, 52, 357-364.

Ashfia F., Adriane F., Y., Sari D., P \& Rusmini., 2019. Formulasi Dan Uji Aktivitas Antibakteri Sediaan Footspray Antibau Kaki Yang Mengandung Ekstrak Kulit Jeruk Nipis Dan Ampas Kopi. Indonesia Chemisry And Application Journal. Vol.3, No.1 ISSN: 25492314

Iswandana R., \& Lidya KM., 2017. Formulasi, Uji Stabilitas Fisik, Dan Uji Aktivitas Secara In Vitro Sediaan Spray Antibau Kaki Yang Mengandung Ekstrak Etanol Daun Sirih (Piper Betle L.). Jurnal Pharmaceutical sciences \& Reseach (PSR). Vol.4, No.3. ISSN 2407-2354

Pelczar, Michael J dan Chan E. C. S. 1998. Dasar-Dasar Mikrobiologi Jilid II. Jakarta UI Press.

Riyanta A.B \& Febriyanti R., 2018. Pengaruh Kombinasi Ekstrak Biji Kopi Dan Rimpang Jahe Terhadap Sifat Fisik Sediaan Foot Sanitizer Spray. Jurnal para pemikir. Vol. 7. No. 2. P-ISSN 2089-5313

Rowe, Paul J dan Sian C, (2006). Handbook of pharmaceutical excipient fifthEdition. American pharmacists association. Washington. HIm. 466-469.

Septiani., Dewi E.N., \& Wijayanti I., 2017 Aktivitas Antibakteri Ekstrak Lamun ( Cymodocea rotundata) Terhadap Bakteri Staphylococcus Aureus Dan Escherichia Coli.
Indonesia Journal Of Fisheries Science And Technology. Vol. 13, No.1 : 1-6. ISSN 1858-4748

The Society Of Chiropodist \& Pediatrist, 2011, sweaty feet, http://www.scop.org/foot/health/coomon-footproblem/sweaty-feet/ diakses 4 noverber 2013

White, R.F., 1964. Pharmaceutical Emulsions and Emulsifying Agent 4 Edition. The Chemist and Drugist, London. 